\title{
Influence of Secondary School Inspection on Lesson Planning in Western Uganda
}

\author{
Jerry Bagaya $^{1 *} \quad$ Betty Akullu Ezati $^{1} \quad$ Wycliffe Scot Wafula $^{1} \quad$ Palle Damkjær Rasmussen $^{2}$ \\ 1.College of Education and External Studies, Makerere University, P.O Box 7062, Kampala, Uganda \\ 2.Department of Learning and Philosophy, Aalborg University, DK-9220 Aalborg Ø, Denmark \\ *E-mail of PhD Candidate and Corresponding Author: jbagaya@yahoo.co.uk
}

The research is financed by the Danish Fellowship Centre (DFC) through the Building Stronger Universities Project of Gulu University, Uganda.

\section{Abstract}

School inspection is one of the leading factors in attaining better pedagogy including lesson planning. To that end, any attempt to improve the quality of lesson planning should be given the attention it deserves. This paper, therefore, examines how and to what extent inspection influences teachers' lesson planning in secondary schools in Western Uganda. A concurrent triangulation mixed methods research design involving questionnaire survey and interview, with a total of 399 participants in the categories of school inspectors, teachers, head teachers, and deputy headteachers from 36 secondary school in Western Uganda, was adopted. Quantitative data were analysed using frequencies, ratios and Linear Regression Analysis while qualitative data were analysed using Qualitative Content Analysis. The study revealed that inspection did not significantly influence lesson planning in secondary schools. The study concluded that inspection has not contributed to improving lesson planning in secondary schools in Uganda. The research advances theory on inspection by demonstrating that merely visiting schools to conduct inspections does not necessarily lead to improvement in lesson planning. Improvement rather hinges on the ways that inspectors communicate, with teachers, prior, during and after the inspection. Understanding teachers' beliefs, practices, and perceptions is important for improving educational processes.

Keywords: Inspection, lesson planning, secondary schools, Uganda

DOI: $10.7176 / \mathrm{JEP} / 11-3-01$

Publication date: January $31^{\text {st }} 2020$

\section{Introduction}

Research evidence shows that lesson planning is a professional practice that is at the heart of effective teaching (Dorgu, 2016; Lika, 2017; Nesari \& Heidari, 2014). For example, Dorgu (2016) stated that lesson planning leads to more learning since the teacher has reflected on what needs to be done to bring about desired changes in the learners. Nesari and Heidari (2014) observed that teachers should not go to class without a lesson plan since it is a pre-requisite for effective teaching. According to Lika (2017), lesson planning helps in aligning teaching with curriculum goals and objectives; ensuring that every learner's needs are met with confidence.

In Ugandan secondary schools, however, most teachers are apparently teaching with sketchy and outdated schemes of work and lesson notes, and no lesson plans despite the massive investments in and restructuring of the school inspection system in Uganda to ensure quality of teaching and learning. These practices are reflected in the predominant use of teacher-centred methods (Education Standards Agency, 2003; Lugujjo, 2008; Ministry of Education and Sports (MoES), 2007; Winkler, Sondergaard, Nannyonjo, Habyarimana, \& Shkaratan, 2008) in addition to assessment results not being used to help learners progress (Directorate of Education Standards, 2008a, 2008 b 2011) and lack of adherence to the national curriculum (Uganda National Examinations Board (UNEB), 2012; UNEB, 2014).

The problem of poor lesson planning reflects the inadequacy of the Ugandan education system. This scenario raises the question as to whether the apparent problems with lesson planning could be attributed to inspection. While evidence for the influence of inspection on school performance has been established, there is a dearth of studies on the influence of inspection on lesson planning. Even so other studies have posted mixed and contradictory results (Lee, Ding, \& Song, 2008; Perryman, 2010; Ventura, 2007). The objective of this paper, therefore, is to examine how secondary school inspection influences teachers' lesson planning in Western Uganda. To achieve this objective, the hypothesis that there is no statistically significant influence of secondary school inspection on lesson planning in western Uganda was tested.

\section{Review of Related Literature}

\subsection{Theoretical Review}

Habermas's Theory of Communicative Action (TCA) postulates that: "actors in society seek to reach a common understanding and to coordinate actions by reasoned argument, consensus and cooperation rather than strategic action strictly in pursuit of their own goals." (Habermas, 1984:86). The theory emphasizes widespread participation by all stakeholders and reaching consensus on the plan of action through stakeholder dialogue without 
exercise of power (Han, 2002; Mitrović, 1999; Salleh \& Tan, 2008; Terry, 1997). This does not mean that strategic action and power differentials are absent, but rather that communicative coordination is the core of communities and societies, and should be deliberately pursued. As applied to this study, TCA holds that inspectors can only be considered as change agents when their interactions with teachers are coordinated through a medium of language and discourse on a plan of action for improvement, thereby modifying the way teachers think and act. In this way, the theory makes a contribution to a better understanding of how inspection works to induce change in schools.

\subsection{Inspection and Lesson Planning in Educational Institutions}

Inspection is considered as an important element in improving the efficiency and effectiveness of any education system (Fergusson, 1998; Govinda \& Tapan, 1999). Despite the perceived role of inspection, there has been little research on the influence of inspection on lesson planning. Significant literature on inspection in developing countries including Uganda is virtually non-existent. A number of studies carried out in other countries point to poor quality of inspection owing to inadequate resources.

Studies that have found positive results of the influence of inspection on lesson planning include those by Blase and Blasé (2000), Ehren and Visscher (2008) and Adegboyega (2012). Blasé and Blasé (2000) studied teachers' perspectives on how principals promote teaching and learning in schools using 809 American teachers. The study revealed effective instructional leadership to be characterised by: "talking with teachers to promote reflection and promoting professional growth" (p. 130), that enhanced planning, teacher efficacy and instructional variety in teaching. The study suggested that effective inspection positively influenced teaching practices, including planning for instruction. Given, however, that the study was conducted in a developed country with adequate resource allocation, findings may not necessarily apply to Uganda, a developing country. In addition, the study concerned instructional supervision by the principals, and not by inspectors, from the teachers' perspectives. The current study incorporated the views of inspectors, headteachers and teachers.

To address the question: 'What effects, if any, do school inspections have on school improvement?' Ehren and Visscher (2008) conducted questionnaire and interview survey with 54 school inspectors of Dutch primary schools. Case studies from 10 schools between 2002 and 2005 were selected. Data was gathered by interviews, questionnaire, observation and document analysis. The study showed that schools started to improve after an inspection visit. The study considered improvement as "actions which schools take in order to improve the achievement levels of their students" (p. 209) in all school activities while the current study focused on lesson planning. These findings are supported by Adegboyega (2012), who examined supervisory strategies as correlates of quality education among 30 secondary schools in Ibadan, Nigeria with a sample of 280 teachers and 20 supervisors. Adegboyega found that supervisory strategies significantly predicted quality education $(F(4,295)=$ 261.225 ). The results probably suggest that inspection, if well done, can enhance quality of education. The study considered different types of supervisory strategies (companionable, synergistic, laissez-faire, and authoritarian) while this study focused on inspection characterised by inspection practices. In addition, this study was interested in specific aspects of quality education that are directly influenced by inspection. As such, pedagogy and more specifically lesson planning being a core school activity was the focus of the study rather than consider the broad concept of quality education.

Other studies have found conflicting or negative results. For example, in examining the effects of school inspection, De Wolf and Janssens (2007) found out that literature presented mixed results with some studies revealing positive effects while others provided negative effects. Studies, mainly conducted in the United Kingdom, show that inspection results in changes in teaching strategies and consequently in school improvement. On the other hand, De Wolf and Janssen's review of literature highlights empirical evidence on the negative effects of inspection including teaching to satisfy inspectors and stress. Since there is considerable difference in the findings of the reviewed literature and methodological variations, De Wolf and Janssen called for more research into the effects of inspection but with improved methodologies. The present study was partly a response to this call. Other negative results are in Varnava and Koutsoulis's (2006) quantitative study of 200 teachers in Cyprus in which the teachers perceived inspection as not enhancing teaching practices. Being purely quantitative, the research did not provide an understanding of underlying reasons to teachers' perception and therefore did not provide more indepth information about the problem. The current study adopted mixed methods to take advantage of the high predictive power of quantitative research and the in-depth nature of qualitative research to better understand the research problem. The findings above corroborates those of National Association of Schoolmasters Union of Women Teachers [NASUWT] (2011) who found out that inspection significantly increased workload on teachers as they were burdened with preparation of lesson plans in specific formats. The study did not, however, indicate whether the increased workload had any significant influence on the quality of lesson planning.

According to Volante (2004) and Styron and Styron Jr. (2012), due to pressure from stakeholders for teachers to produce high test scores in highly publicised tests, there is a tendency for teachers to skew their teaching plans focusing only on the activities that are assumed to lead to attainment of high scores on the test. These maladaptive preparation strategies tend to hinder more than promote effective preparation since teachers predominantly plan 
for teacher-centred pedagogies (Zhao, Mu, \& Lu, 2016). Most of the instructional time is used to prepare for and administer tests, while abandoning the approved curricula. Popham (2001) adds that teachers have, as a result of enormous pressure to raise students' scores on high stakes tests, resorted to test targeted instruction; yet there is limited teacher capacity and skills to effectively use assessment information in improving learning (Sayed \& Kanjee, 2013).

In a recent study by Habyarimana, Kacker, and Sabarwal (2017), an examination of teacher self-beliefs on effort and ability in Public-Private Partnership (PPP) schools in Uganda found out that the average teaching time in a day was only 2 hours 20 minutes. In addition, $89 \%$ of the teachers claimed to have prepared schemes of work while only $67 \%$ claimed to have prepared weekly lesson plans. The majority of the teachers $(61 \%)$ indicated that their performance was evaluated based on student performance in national examinations. What influence then does school inspection have on the quality of lesson planning in secondary schools in Uganda?

The literature relating to inspection and lesson planning has been considered. The reviewed studies centred mainly on inspection in developed countries and basic education. This study, therefore, sought to extend the limited work done in Uganda so that the influence of inspection could be tested out on a much larger sample of teachers, headteachers and inspectors using mixed research methods.

\section{Research Methodology}

Pragmatism is the philosophical underpinning that was adopted for this study. Under pragmatism, researchers use methods that provide the best answers to research questions rather than their representative accuracy and therefore facilitate the realisation of richer conclusions (Creswell, 2009). In order, therefore, to more effectively examine the issue under investigation, the Concurrent Triangulation Mixed Methods Research Design was adopted in which both qualitative and quantitative approaches were used for the purpose of breadth, depth of understanding and corroboration. In this design, both quantitative and qualitative data were collected at roughly the same time but were analysed separately and independently using traditional techniques associated with each data type.

To investigate the problem, a sample of 22 inspectors, 39 headteachers and 36 deputy headteachers and 302 teachers from 36 secondary schools in Buliisa, Masindi, Kasese and Kyenjojo districts of Western Uganda. Region and Districts were purposively sampled since regions are homogeneous with respect to inspection practices by DES and teaching practices while districts selected had a diverse range of characteristics relevant to phenomenon under study. Stratified Random Sampling was used to select the schools. The secondary schools in the selected districts were stratified in two ways. The first stratification was based on location of the schools so as to include both rural and urban schools. The second level of stratification was based on school status, ensuring that both public and private secondary schools were included. After the schools were sampled, the researcher used Simple Random Sampling to select the teachers. The selection of schools and districts automatically implied the selection of headteachers and/or deputy headteacher and inspectors respectively.

In order to collect relevant data from the respondents, the study used questionnaires and interview guide. A structured 5-point Likert scale questionnaire was administered to respondents while the interview guide was used to collect data from key informants. Validity was ascertained using Content Validity Index (CVI). The S-CVI/Ave method yielded values of 0.917 and 1.00 for the questionnaire and interview guide respectively. Therefore, the instruments were considered to have high content validity. To determine reliability, a pilot test was conducted and Cronbach's Alpha computed, gave a value of 0.753 , indicating a high internal consistency.

Data collected with the questionnaire were analysed using both descriptive and inferential statistics. Frequencies and ratios were used to describe the data while linear regression analysis was used to test the hypothesis at 0.05 level of significance. IBM SPSS 20.0 was used to support the analysis process. Interview data were analysed using qualitative content analysis with the support of Atlas.ti7 software.

\section{Results/Findings}

Table 1.Perceptions of Respondents on Influence of Inspection on Lesson Planning

\begin{tabular}{|l|r|r|r|r|c|c|}
\hline \multicolumn{1}{|c|}{ QUESTIONNAIRE ITEM } & SD & D & UD & A & SA & Ratio \\
\hline $\begin{array}{l}\text { As a result of inspection, teachers consistently prepare schemes of } \\
\text { work and lesson plans. }\end{array}$ & 27 & 69 & 45 & 179 & 57 & 0.407 \\
\hline $\begin{array}{l}\text { As a result of inspection, teachers prepare departmental rather than } \\
\text { individual schemes of work. }\end{array}$ & 34 & 147 & 41 & 127 & 28 & 1.168 \\
\hline School inspection has an influence on the way teachers plan lessons. & 15 & 38 & 32 & 226 & 66 & 0.182 \\
\hline $\begin{array}{l}\text { Teachers' mastery of the subject and pedagogical skills as seen in their } \\
\text { planning are enhanced as a result of inspection. }\end{array}$ & 54 & 117 & 40 & 138 & 28 & 1.030 \\
\hline $\begin{array}{l}\text { DES inspection has made teachers more creative in the way they plan } \\
\text { lessons. }\end{array}$ & 23 & 50 & 40 & 203 & 61 & 0.277 \\
\hline $\begin{array}{l}\text { Inspections have enabled teachers to stimulate interest in topics by } \\
\text { emphasising their rationale at planning phase. }\end{array}$ & 18 & 57 & 50 & 206 & 46 & 0.298 \\
\hline
\end{tabular}




\begin{tabular}{|l|c|c|c|c|c|c|}
\hline \multicolumn{1}{|c|}{ QUESTIONNAIRE ITEM } & SD & D & UD & A & SA & Ratio \\
\hline $\begin{array}{l}\text { Due to inspection, teachers now plan to use instructional materials to } \\
\text { aid the teaching-learning process. }\end{array}$ & 21 & 46 & 41 & 198 & 71 & 0.249 \\
\hline $\begin{array}{l}\text { School inspections have aided teachers in planning to address } \\
\text { challenges of learners with special needs. }\end{array}$ & 30 & 74 & 54 & 173 & 46 & 0.475 \\
\hline
\end{tabular}

The objective of the study was to examine how secondary school inspection influences teachers' lesson planning in Western Uganda. Table 1 shows the frequency table of the cross-tabulation of each of the eight items on the influence of inspection on lesson planning and the relevant response rating as strongly disagree (SD), disagree (D), undecided (UD), agree (A), strongly agree (SA).

Column 7 of Table 1 shows that only two items relating to preparation of departmental schemes of work and enhancement of teacher's mastery of the subject matter and pedagogical skills as a result of inspection was negatively perceived by the respondents, representing $25 \%$ of the items in the lesson planning subscale. The other six items concerning the influence of inspection on lesson planning, creativity, stimulation of learner interest in subjects, use of instructional materials, and addressing challenges of learners with special needs were positively perceived. These results suggest that inspection positively influenced lesson planning in the study schools.

A Simple Linear Regression Analysis was conducted using IBM SPSS 20 to determine if lesson planning could be predicted from inspection. The null hypothesis tested was that the regression coefficient (i.e. the slope) was equal to zero. The data was screened for missingness and violation of assumptions prior to analysis. There was no missing data and the assumptions of linearity, independence, and normality were met. The assumption of homogeneity of variances, however, was violated. Despite this violated assumption, the linear regression analysis was run because it is quite robust to violating the assumption about equality of variances (Keith, 2006; Wilcox, Granger, \& Clark, 2013).

The results of the Simple Linear Regression Analysis in Table 2 and Table 3 suggest that a statistically significant proportion of the total variation in lesson planning was predicted by inspection, $F(1,375)=90.160$, $p$ $<.05$.

Table 2: Analysis of Variance - Inspection and Lesson Planning

\begin{tabular}{|c|c|c|c|c|c|c|c|c|}
\hline \multicolumn{2}{|c|}{ Model } & \multicolumn{2}{|c|}{ Sum of Squares } & $d f$ & \multicolumn{2}{|l|}{ Mean Square } & $F$ & Sig. \\
\hline \multirow[t]{3}{*}{1} & Regression & \multicolumn{2}{|c|}{2637.330} & 1 & \multicolumn{2}{|l|}{2637.330} & \multirow[t]{2}{*}{90.160} & \multirow[t]{2}{*}{.000} \\
\hline & Residual & \multicolumn{2}{|c|}{10969.396} & 375 & \multicolumn{2}{|l|}{29.252} & & \\
\hline & Total & \multicolumn{2}{|c|}{13606.727} & 376 & & & & \\
\hline \multicolumn{4}{|c|}{ Table 3: } & & \multirow{4}{*}{$T$} & \multirow{4}{*}{ Sig. } & & \\
\hline \multirow{3}{*}{\multicolumn{2}{|c|}{ Model }} & \multicolumn{2}{|c|}{$\begin{array}{l}\text { Unstandardized } \\
\text { Coefficients }\end{array}$} & $\begin{array}{l}\text { Standardized } \\
\text { Coefficients }\end{array}$ & & & \multicolumn{2}{|c|}{$\begin{array}{l}\text { 95.0\% Confidence } \\
\text { Interval for B }\end{array}$} \\
\hline & & \multirow[t]{2}{*}{$\mathrm{B}$} & Std. & Beta & & & Lower & Upper \\
\hline & & & Error & & & & Bound & Bound \\
\hline \multirow[t]{2}{*}{1} & (Constant) & 5.077 & 2.349 & & 2.162 & .031 & .459 & 9.695 \\
\hline & $\begin{array}{l}\text { Nature of } \\
\text { Inspection }\end{array}$ & .179 & .019 & .440 & 9.495 & .000 & .142 & .216 \\
\hline
\end{tabular}

Additionally, we found the following:

The unstandardized slope (.179) and standardized slope (.440) are statistically different from zero, $t(375)=$ $9.495, p<.05$ (Table 3). Specifically, we would expect a one-unit increase in inspection to produce .179 increase in lesson planning.

From Table 3 , the confidence interval around the standardized slope does not include zero $(.142, .216)$, further confirming that inspection is a statistically significant predictor of lesson planning. The intercept (i.e. the level of lesson planning when there is no inspection) was 5.077. The value of the Coefficient of Determination, $R$ squared, indicates that $19.4 \%$ of the variance in lesson planning is explained by inspection. According to Cohen (1988), this suggests a moderate influence.

In summary, a linear regression established that inspection could statistically significantly predict lesson planning $F(1,375)=90.160, p<.05$ and that inspection accounted for $19.4 \%$ of the explained variability in lesson planning. The regression equation was:

\section{Lesson Planning $=\mathbf{5 . 0 7 7}+\mathbf{0 . 1 7 9} *($ Inspection $)$}

The interviewees, on the other hand, revealed various understanding, experiences and perceptions when asked what changes they had observed in lesson planning as a result of inspection. The majority of the participants were of the view that secondary school teachers tended not to make lesson plans but rather opted for schemes of work. Some participants indicated that school inspection could have some influence on lesson planning, but that this influence was not necessarily positive. Teachers implied this narrative when they stated: "Secondary school teachers usually don't make lesson plans. They have been dodging it. They scheme and just go straight to teach", and "... teachers, they do lesson plan after lesson planning, they do not normally follow them." 
Consistent with the experience of teachers, headteachers observed that: "now you know in secondary, for example, many teachers do not draw that lesson plan, usually they make lesson notes", and ... I don't want to deceive you. Most schools ... in rural schools, most teachers don't lesson plan but they have schemes of work. They have schemes of work, they have lesson notes but real lesson planning as it was in the training college, is not common.

Adding that:

... Actual lesson planning in most cases is not there like we have them may be in primary schools. So much so that you find these teachers moving from school A, B, C, D because they have a line of schools where they part-time, and they hover along with the so-called yellow notes. You find the book is 10 years old; one is just moving with it. They don't take time to update their notes and so on.

Another headteacher observed:

To be honest, sometime back it was sort of havoc. Most teachers had run out of the professional way of conducting the educational business particularly by ensuring that these preparations are done. We would see a scenario where a teacher only prepares lesson notes without the scheme of work and lesson plans.

Inspectors agreed with the teachers and headteachers but even raised more concern with the quality of lesson planning in secondary schools despite inspection. Two of the inspectors described the challenge of lesson planning as:

I can say there are no changes because generally in secondary schools, lesson planning is a challenge. Teachers rarely make lesson plans and if they are to make them, they are making for inspectors and so they are sketchy, scanty, not orderly, and not for use but to keep; to just show someone that they are using them. Generally, lesson planning is poor. I can say it is not there almost.

Another inspector, in support, noted:

Lesson planning is generally poor. If I were to rate according to our observations, lesson planning is very poor in secondary schools. But during the training, they always undergo courses of preparing lessons and even keeping records that are very good in teachers' colleges and universities. But practically on the ground, I can rate that may be over $85 \%$ of them via scheming they are there but lesson planning they are very poor in it.

The qualitative data corroborates the quantitative findings that there is a statistically significant positive, though moderate, influence of inspection on lesson planning. There were several instances of agreement between the data sets, and for many, qualitative data helped to explain findings in the quantitative data and offers a basis for deeper understanding. For example, there seems to be agreement that preparation of schemes of work improved as a result of inspection while the use of lesson plans generally remained minimal.

\section{Discussion of the Results/Findings}

The study revealed that inspection had some influence on preparation of schemes of work in secondary schools, but that the practice of lesson planning was limited and that the influence of inspection was not only positive. This is inconsistent with the findings by Adegboyega (2012), Blasé and Blasé (2000), and Ehren and Visscher (2008), which posited positive results on the influence of inspection on lesson planning, albeit as components of the teaching and learning process.From theory, it is expected that inspection should improve teacher performance and therefore lesson planning. Lesson planning is the foundation of effective teaching and learning because planning to achieve goals and objectives is an essential first step in any process, and the teaching and learning process is no exception (Haynes, 2010; Heidari, Azizifar, Gowhary, \& Abbasi, 2015; Kimosop, 2015; Ramaila \& Ramnarain, 2014). Due to the surprise nature of inspections coupled with short duration, teachers may not be accorded adequate time to raise issues and examine what they do and deliberate about the issues with the inspectors who are considered to have fresh ideas and outlooks. According to Mc Cutcheon (1980),

access to new ideas is important, not merely for the sake of newness, but also because of the opportunity it offers for teachers to reflect on the appropriateness of continuing to do things as they have been done in the past. (p. 13)

The other reason could be that teachers only tended to prepare lesson plans during practicum or a few years into the teaching profession. After that, they tended to use mental planning; which unfortunately is not recognised in educational theory and practice. This view is supported by Moradan and Pourasadollah (2014) who found out that senior teachers did not usually use lesson plans despite recognising their importance. According to Moradan and Pourasadollah (2014), the majority of older, experienced and less-educated teachers did not use lesson planning as opposed to younger and novice teachers. Further support is from Kimosop (2015), who pointed out that the majority $(55.5 \%)$ of the teachers who made schemes of work never referred to them and that $69 \%$ of the teachers thought it was not necessary to make lesson plans; revealing that lesson plans were only necessary during school practice.

Another reason for the inadequate preparation of lesson plans is the examination-oriented nature of teaching that has resulted in teachers spending a significant amount of time on assessment (Ramaila \& Ramnarain, 2014). 
The majority of schools in Uganda conduct three major assessments in a term: beginning of term, mid-term and end of term examinations. This means that teachers are pre-occupied with setting, marking and revision of the tests. Planning lessons demands a lot of time of the teachers, which time is not readily available due to heavy workload. Examination-oriented teaching stifles teacher innovativeness since teachers only put much emphasis on the art of answering questions in an examination. Examinations, and not inspection seem to be the most powerful determinant of classroom activities, with teachers teaching to the test (Habyarimana et al., 2017; Popham, 2001; Sayed \& Kanjee, 2013; Styron \& Styron Jr., 2012; Volante, 2004; Zhao et al., 2016), without regard to the needs of the students.

In light of this research, the findings and arguments therein seem to support the application of Habermas TCA at a micro-level within the school system. Explaining inspection effects using TCA seems to be well founded since the interaction between inspectors and teachers is essentially a communication (speech acts) through which the inspector seeks to influence the actions of teachers. From this study, drawing from Habermas' concepts of communicative action and strategic action, inspectors in secondary schools in Western Uganda appear to influence teacher actions in a strategic way, steered by power and manifested in traditions, by-laws, and state apparatus. As a result, this attempt seems to be unsuccessful as revealed by the study. This is of course not necessarily a conscious practice of inspectors; it may be seen as a result of the institutional environment in which the inspection system operates.

The finding that teachers most often do not prepare lesson plans and when they do, it is for the inspection purpose suggest that inspectors do not enter into a communicative exchange with teachers, in which each actor presents and argues his/her views with a view to reaching a common understanding via rational discourse, and subsequently an agreed action plan for improvement. Under such arrangement, the inspection may be perceived by the teachers as threatening (Ehren, 2016). This clearly reveals the inherent power differences between inspectors and teachers, in which authorities and traditional views should not be questioned and challenged (a form of colonisation of teachers) - typical of power vested in a hierarchical academic system. For inspection, therefore, to positively influence lesson planning, inspectors should use reasoned justification and argument to change the way teachers think and act (Han, 2002; Salleh \& Tan, 2008; Terry, 1997).

\section{Conclusions}

The study investigated the influence of inspection on lesson planning in secondary schools in Western Uganda. This was in relation to the dearth of studies on the influence of inspection in middle- and low-income countries. The study established that while inspection had some limited influence on lesson planning, this influence was not only positive and lesson planning generally remained at a low level. In view of this finding and the discussions thereof and in tandem with the research objective, we conclude that despite reports on the value of inspection in the theoretical, political, institutional and policy debates, this study suggests that inspection has not significantly contributed to improving lesson planning in secondary schools in Uganda. Teachers tend to only prepare lesson plans either after practicum when they transition from student teachers to teachers or when they anticipate that they are likely to be supervised or inspected. Could teachers be losing touch with professionalism? Or can experienced teachers claim to teach effectively without lesson planning?

\section{Implications of the Research}

The theoretical contribution of this research is in the application of the TCA to explain the complex interaction between inspectors and teachers aimed at pedagogical improvement; thereby advancing the existing theory. This research advances theory on inspection by demonstrating that merely visiting schools to conduct inspections does not necessarily lead to improvement. It is rather a question of how the inspectors communicate, with the key stakeholders, prior, during and after the inspection, to minimise negative effects of inspection. Thus, the research provides a unique theoretical contribution to TCA by enhancing our understanding of the process of inspection and how it can lead to improvement in lesson planning practices.

One of the findings was that teachers rarely prepared lesson plans yet, theoretically, lesson planning is a major pre-requisite for successful teaching and learning. It is therefore imperative for researchers to explore the current teachers' lesson planning practices and their perceptions of how the lesson plans facilitate effective teachinglearning process. Furthermore, factors within the school setting or education system that hinder the preparation and use of lesson plans in secondary schools in Uganda could be studied. Understanding teachers' beliefs, practices, attitudes and perceptions is important for improving educational processes.

\section{References}

Adegboyega, B. I. (2012). Correlates of Supervisory Strategies and Quality Education in Secondary Schools in Oyo State, Nigeria. International Journal of Learning and Development, 2(3), 164-173. https://doi.org/10.5296/ijld.v2i3.1820

Blase, J., \& Blase, J. (2000). Effective instructional leadership: Teachers'Perspectives on how Principals Promote Teaching and Learning in Schools. Journal of Educational Administration, 38(2), 130-141. 
https://doi.org/10.1108/09578230010320082

Bolton, R. (2005). Habermas's Theory of Communicative Action and the Theory of Social Capital. https://doi.org/10.1002/crq.106

Cohen, J. (1988). Statistical and Power Analysis for the Behavioral Sciences (2nd ed.). New York: Lawrence Erlbaum Associates.

Creswell, J. W. (2009). Research Design: Qualitative, Quantitative, and Mixed Methods Approaches (3rd Editio). Los Angeles, London, New Delhi, Singapore: SAGE.

De Wolf, I. F., \& Janssens, F. J. G. (2007). Effects and Side Effects of Inspections and Accountability in Education: An Overview of Empirical studies. https://doi.org/10.1016/S1573-448X(89)02006-6

Directorate of Education Standards. (2008a). Report on Inspection of Secondary Schools in Manafwa District. Kampala.

Directorate of Education Standards. (2008b). Report on Inspection of Secondary Schools in Ntungamo District. Kampala.

Directorate of Education Standards. (2011). Report on Inspection of Secondary Schools in Masindi District. Kampala.

Dorgu, T. E. (2016). Different Teaching Methods: A Panacea for Effective Curriculum Implementation in the Classroom. International Journal of Secondary Education, 3(6-1), 77-87. https://doi.org/10.11648/j.ijsedu.s.2015030601.13

Education Standards Agency. (2003). Report on the Inspection Programme 2002/2003. Kampala: Education Standards Agency.

Ehren, M. C M, \& Visscher, A. J. (2008). The relationships between school inspections, school characteristics and school improvement. British Journal of Educational Studies, 56(2), 205-227. https://doi.org/10.1111/j.14678527.2008.00400.x

Ehren, Melanie C.M. (2016). Methods and Modalities of Effective School Inspections (Melanie C.M. Ehren \& K. M. Merki, Eds.). https://doi.org/10.1007/978-3-319-31003-9

Fergusson, V. (1998). Supervision for the self-managing school: the New Zealand experience. In Trends in School supervision. Paris: UNESCO.

Govinda, R., \& Tapan, S. (1999). Quality education through school-based supervision and support : The case of GSS primary schools in Bangladesh. Paris: UNESCO.

Habermas, J. (1984). The Theory of Communicative Action Vo. 1: Reason and Rationalisation of Society (Vol. 1). Boston: Beacon Press.

Habyarimana, J., Kacker, K., \& Sabarwal, S. (2017). Better than Most: Teacher Self-Beliefs in Uganda. Kampala: Authors

Han, G. (2002). An Educational Interpretation of Jürgen Habermas's Communicative Rationality. Asia Pacific Education Review, 3(2), 149-159. https://doi.org/10.1007/BF03024908

Haynes, A. (2010). The Complete Guide to Lesson Planning and Preparation. London, New York: Continuum International Publishing Group.

Heidari, M., Azizifar, A., Gowhary, H., \& Abbasi, Z. (2015). Iranian EFL Teachers' Attitudes towards Lesson Planning based on their Gender. Advances in Language and Literary Studies, 6(4), 80-83. https://doi.org/10.7575/aiac.alls.v.6n.4p.80

Keith, T. Z. (2006). Multiple Regression and Beyond. Boston, MA: Pearson Education Inc.

Kimosop, E. (2015). Teacher preparedness for effective classroom instruction of the secondary school christian religious education curriculum in Kenya. International Journal of Scientific Research and Innovative Technology, 2(12), 63-72.

Lee, J. C. K., Ding, D., \& Song, H. (2008). School supervision and evaluation in China: The Shanghai perspective. Quality Assurance in Education, 16(2), 148-163. https://doi.org/10.1108/09684880810868439

Lika, M. (2017). The impact of curricula and lesson planning in the teaching process. Academic Journal of Business, Administration, Law and Social Sciences, 3(1), 240-247.

Lugujjo, E. (2008). A Critique of the Post-Primary Education and Training. Kampala: Author.

Mc Cutcheon, G. (1980). How Do Elementary School Teachers Plan? The Nature of Influences on It. The Elementary School Journal, 81(1), 4-23.

Ministry of Education and Sports (MoES). (2007). Diagnostic Study on the Causes of Low Primary Education Completion Rates. Kampala: Author.

Mitrović, L. (1999). New Social Paradigm: Habermas's Theory of Communicative Action. Philosophy and Sociology, 2(6), 217-223. from http://www.ceeol.com/aspx/getdocument.aspx?logid=5\&id=a852a46242e54bbe8c144c72dc35928c

Moradan, A., \& Pourasadollah, R. (2014). Teachers' Thinking about their Teaching: A Critical Study on Iranian TEFL Teachers. Procedia - Social and Behavioral Sciences, 98, 1194-1203. https://doi.org/10.1016/j.sbspro.2014.03.534 
NASUWT. (2011). Ofsted inspection: The Experiences of Teachers and School Leaders. Birmingham: NASUWT.

Nesari, A. J., \& Heidari, M. (2014a). The Important Role of Lesson Plan on Educational Achievement of Iranian EFL Teachers' Attitudes. International Journal of Foreign Language Teaching \& Research, 3(5), $25-31$. Retrieved from http://jfl.iaun.ac.ir/article_10884_43a5ff2bb7fbd6998f091eb726f80104.pdf

Nesari, A. J., \& Heidari, M. (2014b). The Important Role of Lesson Plan on Educational Achievement of Iranian EFL Teachers' Attitudes. International Journal of Foreign Language Teaching \& Research, 3(5), $25-31$.

Perryman, J. (2010). Improvement after inspection. Improving Schools, 13(2), $182-196$. https://doi.org/10.1177/1365480210369878

Popham, W. J. (2001). Teaching to the Test? . Educational Leadership, 58(6), 16-20. https://doi.org/10.1017/CBO9781107415324.004

Ramaila, S., \& Ramnarain, U. (2014). Lesson planning practices of South African Physical Sciences teachers in a new curriculum. Johannesburg: University of Johannesburg.

Salleh, H., \& Tan, C. (2008). Habermas and teacher leadership through reflection. New Educational Review, 15(2), 114-125. https://doi.org/10.1016/S1471-4914(02)00009-6

Sayed, Y., \& Kanjee, A. (2013). Assessment in Sub-Saharan Africa: Challenges and prospects. Assessment in Education: Principles, Policy and Practice, 20(4), 373-384. https://doi.org/10.1080/0969594X.2013.849056

Styron, J., \& Styron Jr., R. A. (2012). Teaching to the test: A controversial issue in measurement. Systemics, $\begin{array}{lllll}\text { Cybernetics and } \quad \text { Informatics, } & \text { Retrieved } & \text { from }\end{array}$ https://www.scopus.com/inward/record.uri?eid=2-s2.084896259431\&partnerID=40\&md5=44259a1 ec53e9aeb9a2e5d08b81554a0

Terry, P. R. (1997). Habermas and education: Knowledge, communication, discourse. Curriculum Studies, 5(3), 269-279. https://doi.org/10.1080/14681369700200019

Uganda National Examinations Board (UNEB). (2012). National Assessment of Progress in Education: The Achievement of Senior Students in Uganda in Mathematics, English Language and Biology. Kampala: UNEB.

UNEB. (2014). NAPE: The Achievement of S2 Students in Uganda in English Language, Mathematics and Biology. Kampala: UNEB.

Varnava, M., \& Koutsoulis, M. (2006). Teacher Inspection and in-service Training as means for Teacher and School Improvement. Nicosia: University of Cyprus.

Ventura, A. (2007). What difference does inspection make? Author.

Volante, L. (2004). Teaching to the Test: What Every Educator and Policy Maker Should Know. Canadian Journal of Educational Administration and Policy, (25), 1-6.

Wilcox, R. R., Granger, D. A., \& Clark, F. (2013). Modern Robust Statistical Methods: Basics with Illustrations Using Psychobiological Data. Universal Journal of Psychology, 1(2), 21-31. https://doi.org/10.13189/ujp

Winkler, D., Sondergaard, L., Nannyonjo, H., Habyarimana, J., \& Shkaratan, M. (2008). The Efficiency of Public Education in Uganda. Kampala: Authors.

Zhao, M., Mu, B., \& Lu, C. (2016). Teaching to the Test: Approaches to Teaching in Senior Secondary Schools in the Context of Curriculum Reform in China. Scientifc Research Publishing, 7, 32-43. 